\title{
Assessment of highway infrastructure projects in Latin America and Perú from the competences point of view
}

DOI 10.1515/otmcj-2016-0016

Received June 15, 2016; accepted May 10, 2017

\begin{abstract}
It is stressed that Latin America and Perú should become more competitive. Under the actual development scenarios, attention to competences of programme managers and project managers related to public transportation infrastructure projects has risen substantially.
\end{abstract}

An inefficient bureaucratic system is related with deficiencies of people skills and competences. On the other hand, an excellent system demands quality of the system and quality of people working in it.

Thus, it is important to have excellence in administration and excellent administrators in the public sector. Three main lacking elements have been identified: i) lack of good education; ii) absence of fair salaries in the public sector; and iii) lack of incentives. Many misconceptions and disputed consequences have been observed and analyzed. It is clear that there is lack of competence among infrastructure transport project managers and teams, which causes trouble with the main goal of Peru getting benefits from these investments and achieving sustainable development. Furthermore, the right way to achieve these benefits is through a new model of education for project managers and programme managers in Perú. This education should be based more on competences than on qualifications. Thus, the International Project Management Association (IPMA) competence baseline, which is the standard that best fits to these needs, needs to be implemented to achieve the real contribution and benefits of these projects to society.

Keywords: competitiveness, transport infrastructure, Latin America, Peru, logistics, project management, programme management, competences, ethics, sustainability

*Corresponding author: Germán Gallardo Zevallos, Department of Civil Engineering, University of Piura, Piura, Perú

Tatiana Machicao, Project Management Consultant, Lima, Perú María José Martínez-Echevarría Romero, Department of Construction Engineering and Engineering Projects, University of Granada, Granada, Spain

\section{Context of the Latin American region: the need to be more competitive}

The Global Competitiveness Index (GCI), known as the most comprehensive assessment of national competitiveness worldwide - provided by the World Economic Forum (WEF 2016) shows the ten most competitive Latin American and Caribbean economies. Figure 1 shows the countries and their ranks: Chile (Rank 35), Panama (Rank 50), Costa Rica (Rank 52), México (Rank 57), Colombia (Rank 61), Perú (Rank 69), Uruguay (Rank 73), Brazil (Rank 75), Ecuador (Rank 76) and Guatemala (Rank 78).

"To create sustainable long-term growth, the region must build resilience against external economic shocks. Infrastructure, skills, and innovation-areas in which the region performs relatively poorly-are among the fundamentals to be strengthened. Structural reforms and measures to improve the business environment and to foster innovation, coupled with a better-educated workforce - through more on-the-job training, for example, would increase resilience by diversifying the economy away from commodity price dependence and enable production with more value-added" (WEF 2016).

Vanham (2016) mentioned that 2016 was the year that changed everything for Latin America. In its latest economic report, the International Monetary Fund (IMF) said it expected the region to grow $1.5 \%$ in $2017,2 \%$ more than the projection of this year, which was $-0.5 \%$.

If the Latin America region wants to grow, it needs to fix some aspects in order to be more competitive. In the following paragraphs, the two most important problems will be analyzed. The Peruvian situation will be analyzed in more detail. 


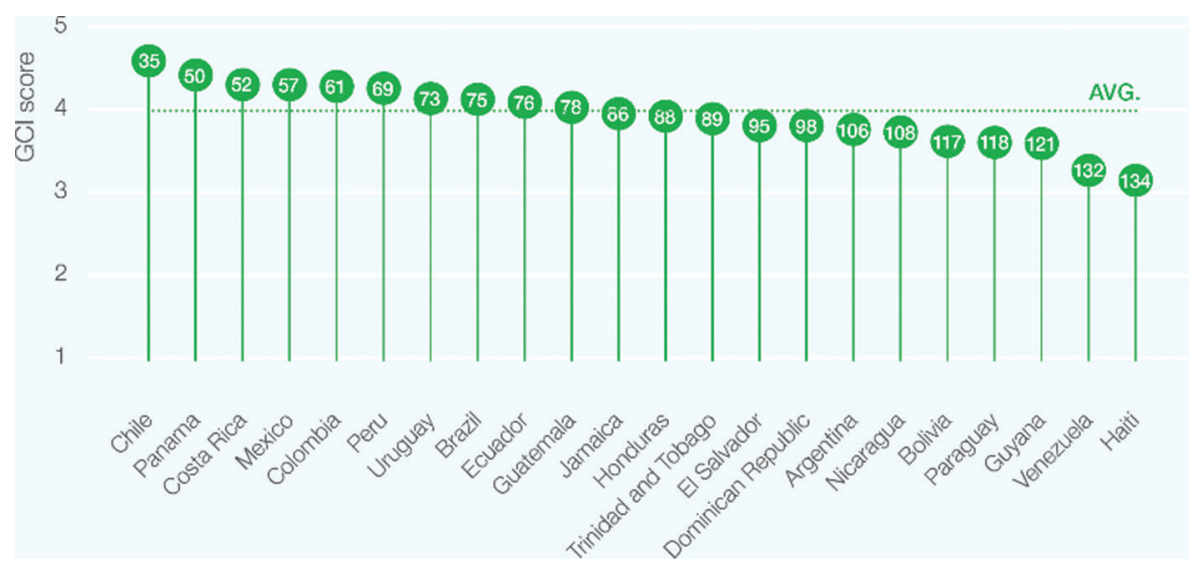

Fig. 1: Regional rankings - Latin America and the Caribbean. Source: The Global Competitiveness Index 2015-2016, World Economic Forum.

\section{Specific areas in which the Latin American region performs relatively poorly}

One important factor to be more competitive is the infrastructure, as pointed out earlier. Particularly, the transportation infrastructure is fundamental and in the case of Latin America, the road network is the most important part of this infrastructure. Latin America needs more number of and better highways to be more competitive.

"Improved infrastructure increases the ability to move goods, services, and ideas within countries and to pass goods and services from one country to another. It decreases transportation costs, and reduces inventory and logistical costs, thereby expanding markets. Improved infrastructure will benefit producers and consumers and will increase the attractiveness of the location for foreign direct investment (FDI). Improved infrastructure also allows for a more equitable distribution of benefits by enhancing the population's ability to take advantage of important health and education services essential for development. Infrastructure has an important role to play in reducing rural poverty; by connecting farmers and/or small business owners in isolated geographic pockets to mainstream markets, infrastructure helps combat their social and economic exclusion" (Kotschwar 2012).

Such is the importance of roads in the development of countries that the World Bank President James Wolfensohn (1995-2005) said, "Transportation in the world is impressive, the low and middle income countries do not have enough highways to help their economies to grow and its citizens to progress. The World Bank's policy to support large infrastructure projects has been reoriented to finance rural roads, so the poor people can get to their jobs and their markets more easily, stock up water and fuel more quickly and go to the schools and reach the health centres more efficiently" (The World Bank 2014). This new policy to do small investments is in tune with the conclusions of other researchers who mention thus: "We thus reject the orthodox theory that heavy investment in Infrastructure causes growth" (Ansar et al. 2016).

Another important factor to be competitive is the building of skills and innovation, as emphasized earlier. This factor is very much connected with education. To diversify the economy towards activities that are more productive, it is necessary to improve the quality of education to provide the necessary skills for a changing economy and promote both the adoption of technologies and the capacity for innovations. These actions require time to develop and bear fruit. A more detailed analysis of the skills required and the execution of highway projects is presented later in this article.

Accordingly, there has been and will be a significant increase in the need for transport of people and goods, which in turn will improve the economy in Latin America. In order to get good results, the building of more numbers of and better highways is a key element, as is the building of the capacities and skills of the Latin American public bureaucracy who will manage these projects.

\section{Context of infrastructure in Peru}

Figure 2 shows Peru's performance in the 12 main competitiveness pillars. In comparison with previous year's WEF report, Peru is improving in five of the 12 pillars: institutions (rank 118 to 116), higher education and training (rank 83 to 82), financial market development (rank 40 to 30), technological readiness (rank 92 to 88 ) and innovation 


\section{Global Competitiveness Index}

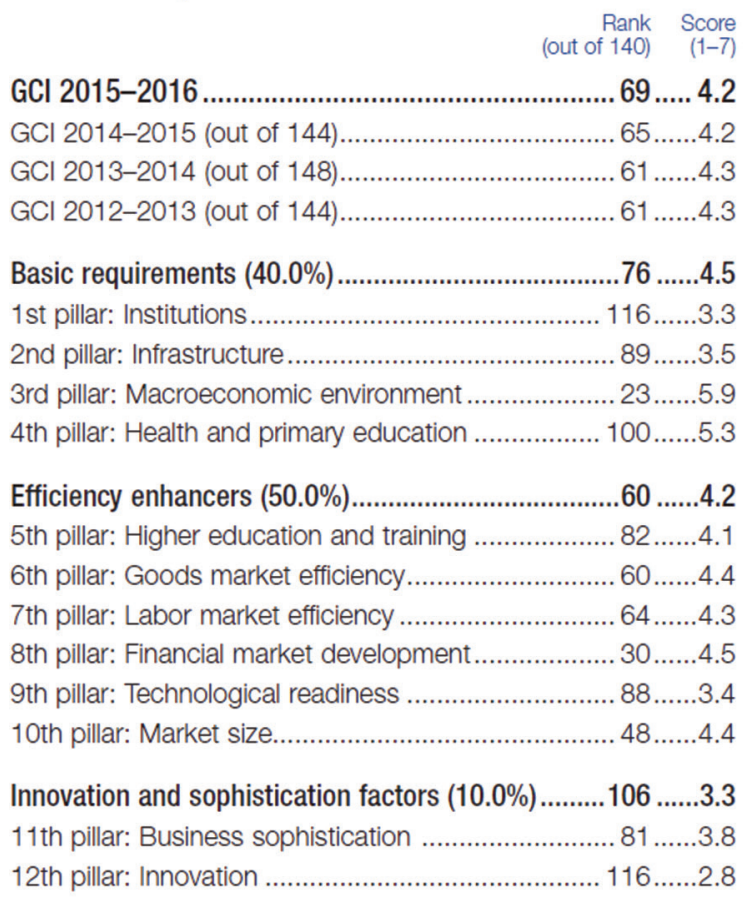

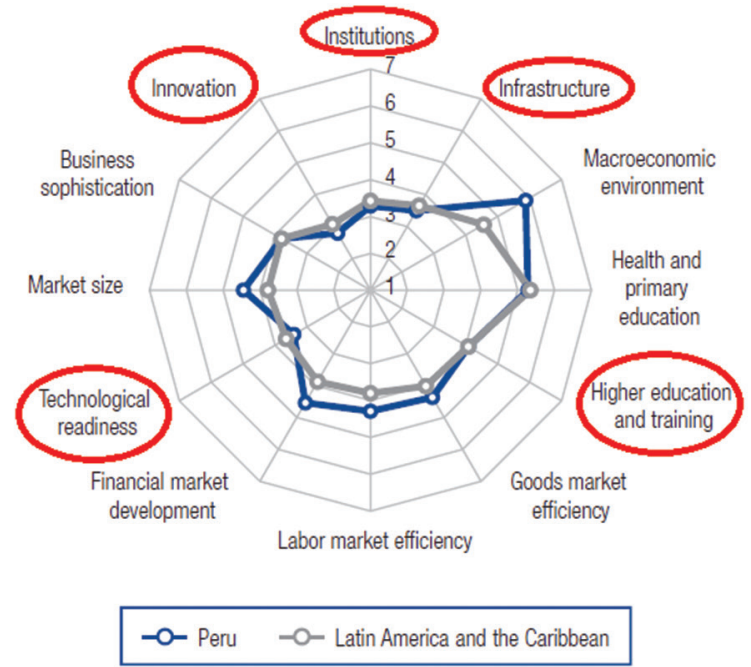

Stage of development

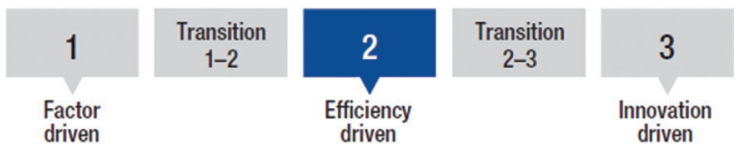

Fig. 2: Peru's performance in the 12 main competitiveness pillars (WEF 2015-2016).

(rank 117 to 116). But these small improvements are not substantial.

In the following seven pillars, there is a descending trend: infrastructure (rank 88 to 89 ), macroeconomic environment (rank 21 to 23), health and primary education (rank 94 to 100), goods market efficiency (rank 53 to 60), labour market efficiency (rank 51 to 64), market size (rank 43 to 48 ) and business sophistication (rank 72 to 81 ).

After this analysis, it can be pointed out that Peru has clear weaknesses in i) technological readiness, ii) innovation, iii) institutions, iv) infrastructure and v) higher education and training, as seen in Figure 2. It is possible to include all of these weaknesses under two factors: infrastructure and people skills or competences, as mentioned before. The latter is influential in technological readiness, innovation, institutions and higher education and training.

Figure 3 shows that the most problematic factors for doing business in Peru include the following: government bureaucracy, restrictive labour regulations, corruption, infrastructure, political instability, crime and theft, among others.

An inefficient bureaucratic system is one in which officers have the following characteristics: application of an excess of labour regulations, corruption, instability, crime, theft, bribery and a fear to take decisions, among others. Many of these issues are very much related - again - with

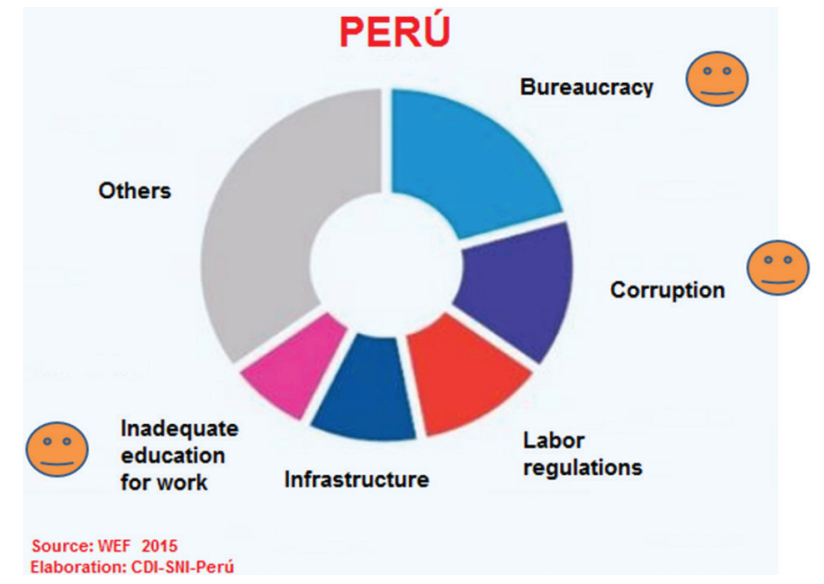

Fig. 3: Main problems for doing business in Perú.

people skills and competences. "Being active participants in the human development of a country like Peru demands of its younger generations very precise skills" is the mission mentioned in the national curriculum (Ministerio de Educación de Perú 2017).

The road network gap in Perú amounts to US\$12.7 billion, which is an important part of the US $\$ 20.9$ billion gap in the total transportation (Asociación para el Fomento de la Infraestructura Nacional, AFIN 2012). Special attention should be given to the work of railroads because of its relation with the traffic of loads and goods. 


\section{Great challenge to face}

Based on the available information in 2012-2021, the gap of infrastructure in Perú is around US\$87,975 millons.

\begin{tabular}{|c|c|c|}
\hline Sector & & $\begin{array}{c}\text { Gap } \\
\text { (Us\$ MM) }\end{array}$ \\
\hline Transportati & & 20,935 \\
\hline & Airports & 128 \\
\hline & Ports & 708 \\
\hline & Railroads & 7,308 \\
\hline & Road networks & 12,791 \\
\hline Water and & Sewage & 5,335 \\
\hline & Drinking water & 1,569 \\
\hline & Sewage Waste water treatment & 3,766 \\
\hline Hydraulic In & frastructure & 8,682 \\
\hline Electricity & & 32,987 \\
\hline & Electricity & 32,297 \\
\hline & Hydrocarbons & 690 \\
\hline Telecommu & nications & 19,170 \\
\hline & Broadband & 11,852 \\
\hline & Mobile telephony & 4,973 \\
\hline & Fixed telephony & 2,345 \\
\hline Health & & 478 \\
\hline \multirow{2}{*}{\multicolumn{2}{|c|}{ Education }} & 388 \\
\hline & & 87,975 \\
\hline
\end{tabular}

Source: Plan Nacional de Infraestructura 2012 - 2021 - AFIN (2012, Lima) Elaboration : OGPP-MTC

Fig. 4: Infrastructure gap in Perú.

After electricity, transportation is the second sector in which Perú needs infrastructure investments. Figure 4 shows more details on this aspect. Important analyses were carried out by AFIN`s Executive Director, who states that "According to the Global Competitiveness Index between 2008 and 2015, the quality of the infrastructure of Peru went from 2.4 to 3.2. Roads also improved from 2.6 to 3.0 points. Although this indicator is calculated with paved roads divided by the total population - in addition to the surveys- it is clear there is a significant gap to pave in the road network, which is an important job of the regional and local governments" (Asociación para el Fomento de la Infraestructura Nacional 2012).

Figure 5 shows how the transportation infrastructure in Perú has developed between 2008 and 2016 (Provias Nacional 2016). The connection between competitiveness and highways is shown clearly in the timeline. In Perú, responsibilities are divided among three levels of government: central, regional and local levels. It is observed that different Peruvian governments are undertaking continuous efforts to improve Peru's highway infrastructure; Figure 6a shows the details of their performance. These improvements are the results of the efforts of the central government that manages the national highways, while at

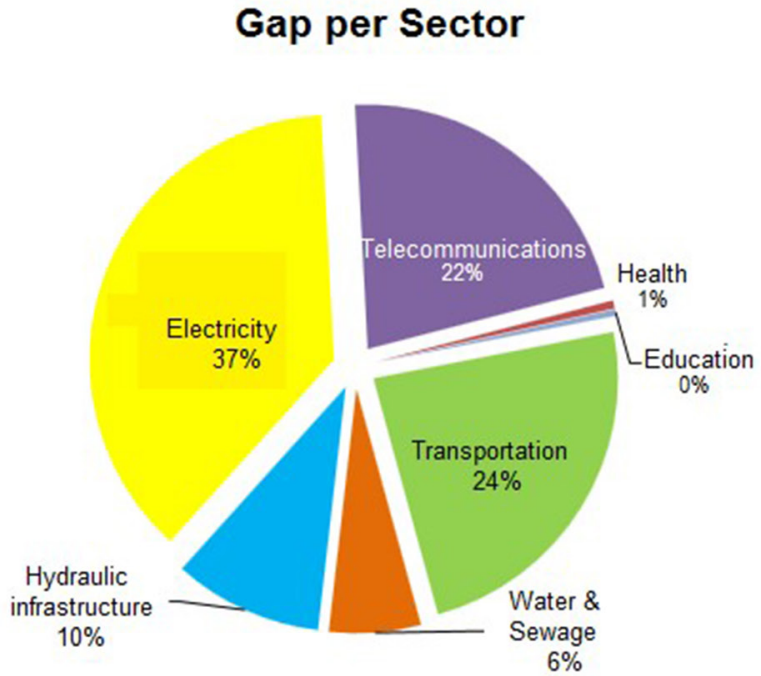

the regional and local government levels, there is much work to be done. Figure $6 \mathrm{~b}$ shows this situation.

\section{The need for excellence in public administration and able administrators in Peru and Latin America}

Since Singapore's independence in 1959, the core principles that have shaped its public administration have been maintained (Jones 1999). From these core principles has evolved a system of public administration characterized by meritocracy in relation to recruitment, promotion, performance appraisal and status, as well as a strong generalist administrative elite involved in policymaking, which permeates the highest echelons of ministries and statutory agencies. It is also characterized by a clear system of performance and financial accountability, and an uncompromising commitment to combat bribery, extortion and other forms of corruption, resulting in one of the most corruption-free bureaucracies in the world (Jones 1999). 


\section{Competitiveness and Highways}

GLOBAL COMPETITIVENESS INDEX - WORLD ECONOMIC FORUM (WEF)

INFRASTRUCTURE QUALITY INDEX

( $1=$ underdeveloped, $7=$ efficient $)$

\begin{tabular}{|c|c|c|c|c|c|c|c|c|c|c|c|c|c|c|}
\hline \multirow{3}{*}{ PERÚ } & \multicolumn{2}{|c|}{ 2008-2009 } & \multicolumn{2}{|c|}{ 2009-2010 } & \multicolumn{2}{|c|}{ 2010-2011 } & \multicolumn{2}{|c|}{ 2011-2012 } & \multicolumn{2}{|c|}{ 2012-2013 } & \multicolumn{2}{|c|}{ 2013-2014 } & \multicolumn{2}{|c|}{ 2015-2016 } \\
\hline & Ranking & Score & Ranking & Score & Ranking & Score & Ranking & Score & Ranking & Score & Ranking & Score & Ranking & Score \\
\hline & 83 & 3.95 & 78 & 4.01 & 73 & 4.11 & 67 & 4.21 & 61 & 4.28 & 61 & 4.25 & 69 & 4.20 \\
\hline $\mathrm{N}^{\circ}$ OF COUNTRIES & \multicolumn{2}{|c|}{134} & \multicolumn{2}{|c|}{133} & \multicolumn{2}{|c|}{139} & \multicolumn{2}{|c|}{142} & \multicolumn{2}{|c|}{144} & \multicolumn{2}{|c|}{148} & \multicolumn{2}{|c|}{144} \\
\hline GLOBAL QUALITY INFRASTRUCTURE & 113,0 & 2.4 & 97 & 2,9 & 92 & 3.6 & 105 & 3,5 & 111 & 3.4 & 101 & 3,6 & 112 & 3.2 \\
\hline Highways & 99 & 2.6 & 93 & 2,9 & 92 & 3.3 & 98 & 3,2 & 100 & 3.1 & 98 & 3,3 & 111 & 3.0 \\
\hline Railroads & 90 & 1.7 & 87 & 1,8 & 91 & 1.9 & 93 & 1,9 & 97 & 1.9 & 102 & 1,8 & 94 & 1.9 \\
\hline Ports & 127 & 2.3 & 126 & 2,7 & 113 & 3.5 & 106 & 3,5 & 111 & 3.5 & 93 & 3,7 & 86 & 3.6 \\
\hline Airports & 94 & 3.9 & 87 & 4,1 & 78 & 4.4 & 70 & 4,6 & 74 & 4.5 & 85 & 4,2 & 82 & 4.1 \\
\hline Available aircraft seat $\mathrm{km} / \mathrm{sem}$, mill & 48 & $(H D)$ & & & 47 & (HD) & 44 & & 42 & $(\mathrm{HD})$ & 40 & $(\mathrm{HD})$ & 42 & (HD) \\
\hline Power quality & 69 & 4.7 & & & 68 & 4.8 & 68 & 4.9 & 74 & 4.8 & 73 & 4.9 & 85 & 3.9 \\
\hline Fixed telephone lines & 96 & $(\mathrm{HD})$ & & & 94 & $(\mathrm{HD})$ & 89 & $(\mathrm{HD})$ & 87 & $(\mathrm{HD})$ & 87 & $(\mathrm{HD})$ & & \\
\hline Mobile telephony subscriptions & & & & & 82 & (HD) & 72 & (HD) & 58 & $(\mathrm{HD})$ & 93 & $(\mathrm{HD})$ & & \\
\hline
\end{tabular}

Fig. 5: Evolution of the $\mathrm{GCl}$ over time in terms of the transportation infrastructure of Perú.

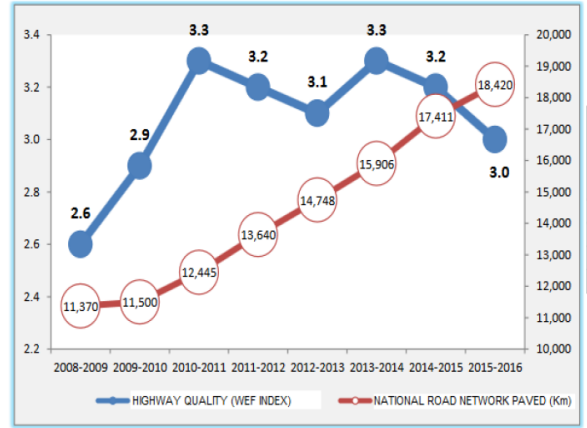

(6a)

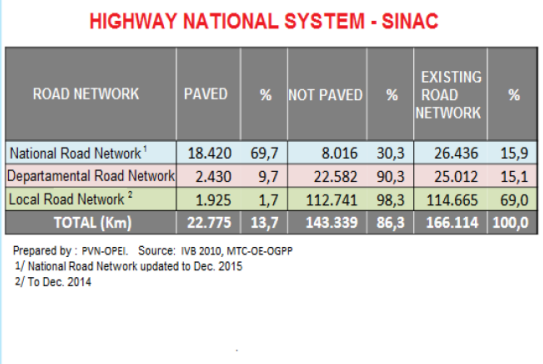

(6b)

Fig. 6: National highway system and evolution of the Highway Quality Index.

Although the core characteristics have been maintained, in recent years, some adjustments have been made, allowing the public bureaucracy to adapt to a rapidly modernizing economy and society, which are also parallel to the trends in public administration in other developed countries. The main change has been the introduction of a business and managerialist ethos into public administration, to promote both efficiency in resource usage as well as improved output and service. Closely related to this has been the corporatization of statutory agencies, contracting of services, deregulation and divestment. Accompanying these changes has been a shift to a more client-centred administration and a limited deconcentration of administrative functions in housing estates through the creation of town councils. Some changes have been reinforced and encouraged in a recent mission statement for the Singapore Public Service regarding its future development, known as "Public Service for the 21st Century" (Jones 1999).

These important characteristics of an excellent public service are the key for competitiveness. Competitiveness focusses not only on the quality of the system but also on the quality of the people who work in the system.

In the case of Peru, low implementation capacity of the Peruvian Public Sector is perhaps the most important problem in the country's development. Improving the effectiveness of the public sector is one of the main tasks of the government (Instituto Peruano de Economía 2012).

Regarding the capacity of public administration in Perú, a World Bank study shows that the effectiveness of the Peruvian government puts it in the 104th place among 192 countries in the world (The World Bank 2014). (Figure 7). In the same order for ideas, in Figure 8, 


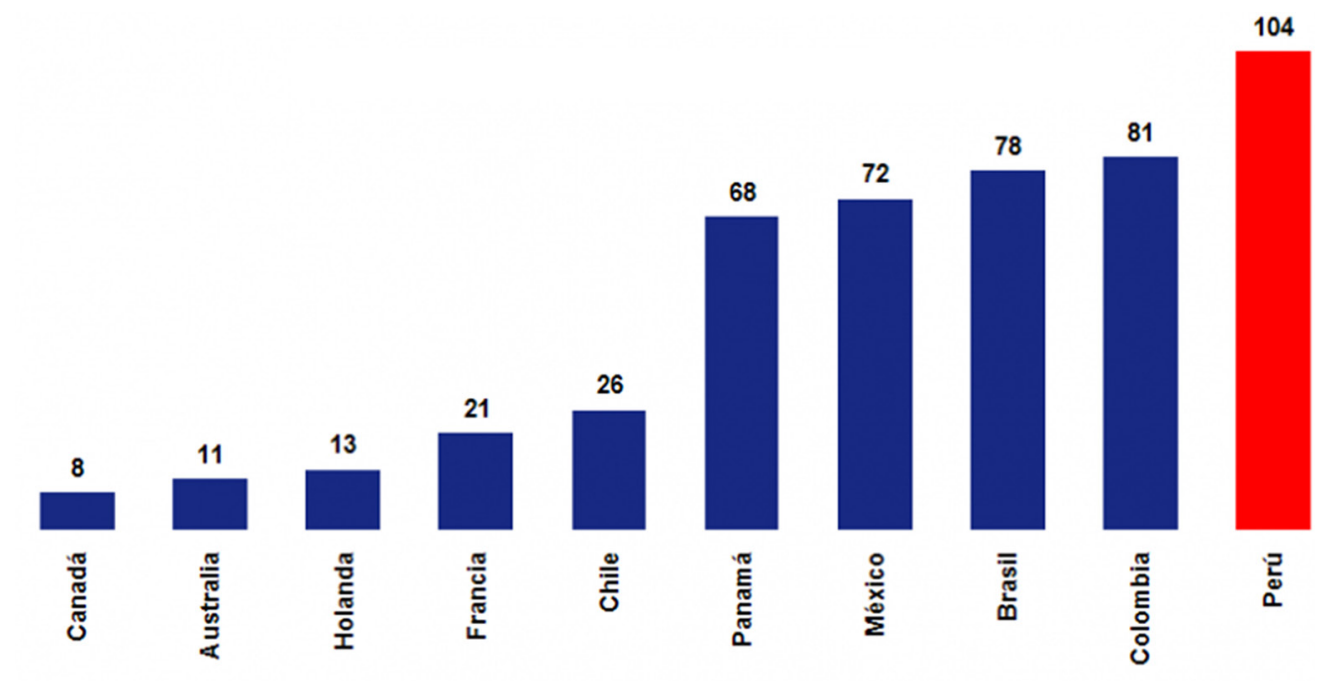

Sources: WEF, World Bank, IBD

Elaboration: Peruvian Institute of Economy (IPE)

Fig. 7: Government effectiveness: ranking of 192 countries.
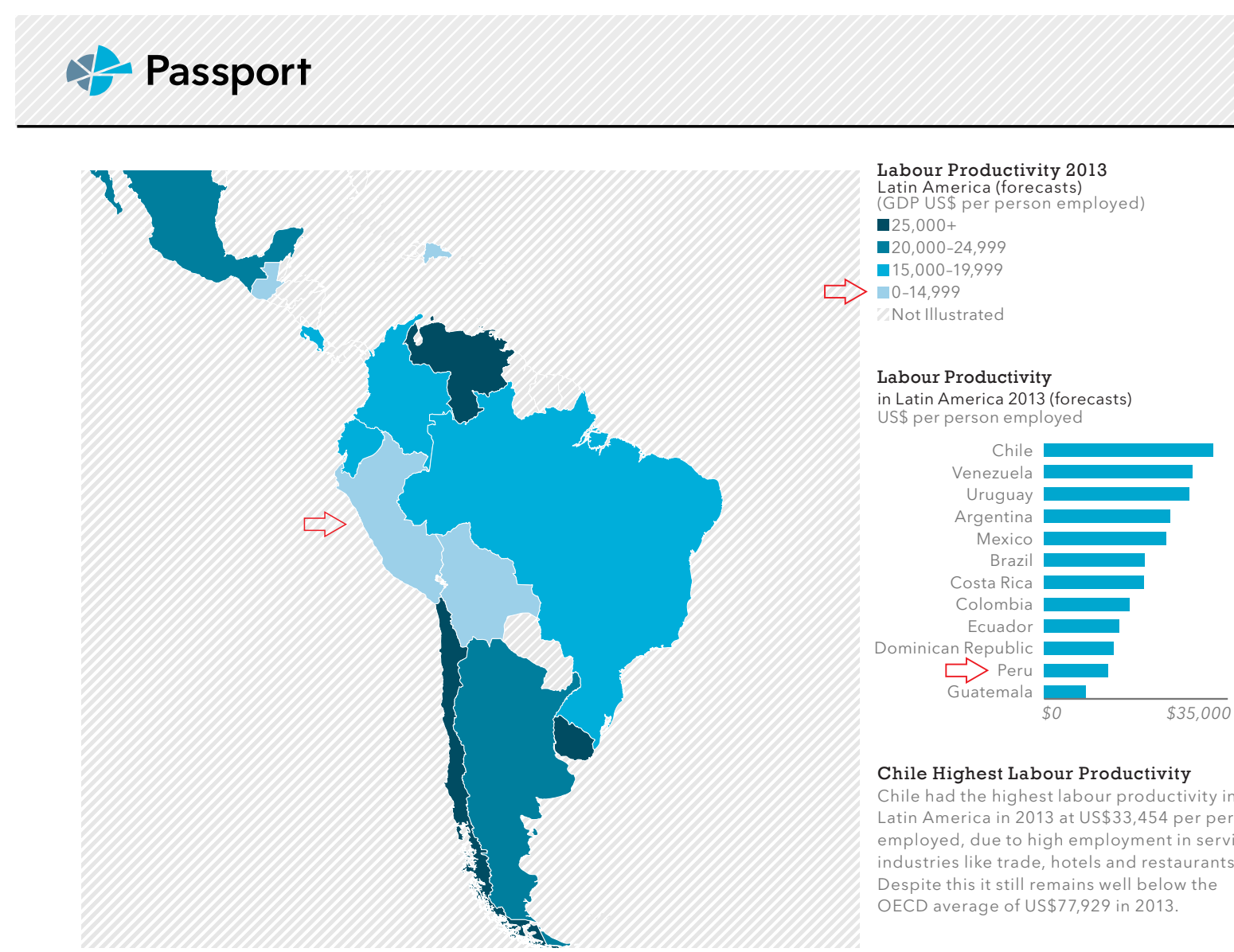

Chile Highest Labour Productivity

Chile had the highest labour productivity in

Latin America in 2013 at US $\$ 33,454$ per person employed, due to high employment in service

industries like trade, hotels and restaurants.

Despite this it still remains well below the

OECD average of US\$77,929 in 2013.

EUROMONITOR

Fig. 8: Labour productivity in Latin America in 2013, showing the position of Perú. 
Peru is in the penultimate position (Euromonitor International 2013).

Latin America is still the region with the highest income inequality in the world (Organisation for Economic Co-operation and Development [OECD] 2016) and this raises an important point to be considered: the salary of the persons who work in the public sector.

The relationship between income and quality of work has been well studied. For example, in order to encourage people to do well, the (Singapore) government believed that an efficient bureaucratic system is one in which the officers are well paid, so that the temptation to resort to bribes would be reduced (Rafique Rahman 1986). On the other hand, there is a big risk if the salary is not appropriate: Van Rijckeghem and Weder (1997) mention that "under fair wage models, civil service wages are an important determinant of corruption".

\section{Uncovered weaknesses}

José Carlos Saavedra, Head of Macroeconomic Analysis of the Peruvian firm Apoyo Consultoría, mentions, "This issue is closely related to education and if we are one of the countries with the poorest results in Latin America, it is clear that productivity should be lower. This is the cost of having a bad education system; and if we have poor results in the Program for International Student Assessment Programme for International Student Assessment (PISA) tests, it is clear that we will also have low productivity, so we must improve on that" (Córdova 2014).

In the ninth national survey on corruption (Proética 2015), $46 \%$ of the people surveyed believed that corruption and bribery are two of the main problems of Peru. They are the most important problems after crime and lack of security. The corruption of officials and authorities is the specific problem of the country, as noted by $61 \%$ of the people surveyed. This fact contributes to loss of trust, and without trust, communication and cooperation as a team cannot be effective in accomplishing goals, as many research reports point (Diallo and Thuillier 2005; Zaghloul and Hartman 2002 Project Management Institute [PMI] 1999).

Then, it is important to have excellence in the administration and excellent administrators in the public sector. Unfortunately, Latin America does not have them due to lack of i) good education, ii) fair salaries in the public sector and iii) lack of incentives given by the different governments to improve and to do their job well.

\section{Assessment of highway infrastructure projects in Peru from the competence point of view}

Perú is clearly moving forward and building highways, but in this effort, the authors have detected important aspects that need to be improved when these projects are being designed or executed. For this analysis, the International Project Management Association (IPMA) Competence Base Line ICB3.0 (IPMA 2006) has been used, which includes 46 competences in three areas: technical, behavioural and contextual.

From the results of a technical survey among master's degree students of Civil Engineering with specialization in Road Engineering at the University of Piura ${ }^{1}$, Table 1 presents the IPMA competence analyzed in its first column (type 1 corresponds to technical competences, type 2 to behavioural competences and type 3 to contextual competences); the second column shows the misconception associated, and the third column explains the consequences for the project and for Perú.

\section{An important factor in the solution}

Under these circumstances and considering all facts, it is important to introduce in Perú a model of managing projects based not only on technical knowledge but mainly on behavioural and contextual competences, i.e. the IPMA model. In fact, the IPMA's vision is as follows: "Promoting competence throughout society to enable a world in which all projects succeed" (IPMA 2006); IPMA looks for generating profound changes in the way people manage projects. It is not just a technical-oriented but a more people-oriented model. Through this model, the change will begin and will reach the public and private sectors. As a major change, this will take time and a lot of effort.

The first critical task is to correct the misconceptions and to improve the competences of project managers in all areas. The right way to do it is through a new model of education for project managers in Peru, which understands that "competence, not qualifications, should be the most important priority when training project managers"

1 The corresponding author leads the Master's Programme for 15 years. 
Tab. 1: Correspondence between competence, misconceptions and consequences.

\begin{tabular}{ll}
\hline Competence & Misconceptions found \\
\hline 1.11 Time and project phases; & $\begin{array}{l}\text { 1. } \\
\text { The design phase of the highway project is } \\
\text { not important. }\end{array}$ \\
$\begin{array}{ll}\text { Quality; } 3.11 \text { Legal basics; and } \\
2.15 \text { Ethics } & \text { 2. } \begin{array}{l}\text { The important part is the construction } \\
\text { phase. }\end{array} \\
& \begin{array}{l}\text { 3. In the bid process, the law rewards the } \\
\text { lowest budget. }\end{array} \\
\text { 4. Contractor's priority: finish the project and } \\
\text { save expenses. }\end{array}$
\end{tabular}

1.03 Project requirements and objectives, 1.09 Project structures, 1.10 Scope and deliverables

1.01 Project management success, 3.08 Personnel management and 2.15 Ethics
1. Contractor of the highway is paid by workload. For example, how many cubic metres of dirt he has moved? On the other hand, the supervisor is paid per day of work.

2. Project ends when the construction phase ends.

1. The main problem is to allocate more resources to projects. At the same time, professionals who work for the public sector must have low salaries. Idea: "It is important to give good example to the citizens".

2. Project managers are chosen for their availability or their approach to the leaders and not necessarily for their skills or competencies.

\section{Consequences}

1. The design phase of the highway project is not important. Therefore, the budget is low, resulting in poor quality.

2. Contractor's priority: ensure to get the project with the lowest budget and once they get the project, ask for additional budget arguing low quality of the design.

3. The additional budget is not for quality improvements but for finishing the project, causes an ethical problem.

4. What happens with other companies who proposed a real budget for better quality? They start legal actions.

The project design and implementation phases is failing

1. Contractor wants to finish early, so he can save overheads and other types of costs. At the same time, the supervisor wants to finish late since he gets payment per day of work. This situation generates many disputes between them.

2. If the project ends with the construction of the highway, this means that there is no maintenance and therefore a strong process of deterioration will begin.

The definition of a project and its deliverables are failing.

Even though resources are available, projects are not implemented due to lack of management capacity.

Other difficulties are technical deficiencies and corruption in regional and municipal governments. There are no trained and proactive people because of the low salary in the public sector.

A project manager inadequately trained and/or untrained can sink a project.

Ending with choosing a project manager who does not have the skills that the project needs.

Need capacity building for effective project managers and quality assurance programmes for organizations.
(Watson 2016). Watson (2016) further provides a definition of competence: "In layman's terms that someone is able to carry out the job as required and expected". "Competence is based on facts; it is not just an opinion. A competence assessment system comprises a standard, a method of providing evidence of competently meeting the standard and a method of quality assurance of how that evidence is collected. This is how project managers should be trained, to maximise their abilities and career success" (Watson 2016).

However, "It must be emphasized that competence does not come from training alone. It is made up of a combination of skill, experience, knowledge and attitude" (Watson 2016).

\section{Conclusions}

Latin America and Perú are receiving constant recommendations from the main world economic organizations about the key aspects needed for their development. They focus on infrastructure, skills and innovation investments.

The infrastructure investment is very much connected with the road infrastructure in Peru, as analyzed in this study. The skills and innovation investment is very much connected with the quality of education.

Specific attention should be given to members of the Public Sector bureaucracy, who are the ones who manage important infrastructure projects. Among other issues, 
they have temptations related with ethics and corruption because of the low salaries and lack of incentives.

Important factors for the lower performance of highway projects in the regional, local and rural areas have been analyzed; a factor that contributes to the much better performance of the highway project under the central government is the better payment.

It is important to have an excellent Public Service not only focussed on the quality of the administration system but also on the quality of the people who are working in the system. It is important to have i) good education, ii) fair salaries in the public sector and iii) different types of incentives to do well.

An assessment of highway projects in Peru was done from the competence point of view and the results show a group of misconceptions and consequences that are rendering all government efforts not as fully effective as they should be. After this analysis, it is clear that the lack of competence in transport infrastructure project managers and teams causes trouble with the main purpose of letting Peru get the benefits of these investments and ensure a sustainable development.

An important factor in the solution is the new system of education for project managers that is proposed. This education should be based more on competences than on qualifications, and it should have a certification model associated with checking of the level of competences developed. The main benefits will be the identification of specific areas of improvement, designing of specific training programmes and defining of clear requirements for job descriptions. In this way, the IPMA competence baseline, which is the standard that best fits these needs, can be implemented.

Finally, if project managers are not competent, because of the lack of a good education system, it is clear that people will suffer; however, the businesses and the society in Peru will also suffer. The IPMA looks for a world where projects that are solutions for people's needs are successful through the improvement of people competences.

\section{References}

Ansar, A., Flyvbjerg, B., Budzier, A., \& Lunn, D. (2016). Does infrastructure investment lead to economic growth or economic fragility? Evidence from China. Oxford Review of Economic Policy, 32(3), pp. 360-390.

Asociación para el Fomento de la Infraestructura Nacional, AFIN. (2012). Por un Perú integrado: plan nacional de infraestructura 2012-2021. AFIN, Asociación para el Fomento de la Infraestructura Nacional, Lima.
Córdova, É. (2014, 04 09). La productividad del Perú es de las más bajas de la región. El Comercio, Perú. Available at http://elcomercio.pe/economia/peru/ productividad-peru-mas-bajas-region-noticia-1721498.

Diallo, A., \& Thuillier, D. (2005). The success of international development projects, trust and communication: An African perspective. International Journal of Project Management, 23(3), pp. 237-252.

Euromonitor International. (2013). Labour Productivity. Retrieved from Labour productivity. Available at http://euromonitor. typepad.com/files/pdf_labourproductivity_2013la-v1.1-1.pdf. Instituto Peruano de Economía. (2012). Abriendo las puertas de la gran transformación. Retrieved from Abriendo las puertas de la gran transformación. Available at http://www.ipe.org.pe/ comentario-diario/26-10-2012/abriendo-las-puertas-de-lagran-transformacion.

IPMA. (2006). IPMA Competence Baseline 3.0. Available at http:// www.ipma.world/assets/ICB3.pdf.

Jones, D. S. (1999). Public administration in Singapore: Continuity and reform. In: Wong, H.K., \& Chang, H. S. (eds.), Handbook of Comparative Public Administration in the Asia-Pacific Basin. Marcel Dekker, Inc, New York, pp. 1-22.

Kotschwar, B. (2012). Transportation and communication infrastructure in Latin America: lessons from Asia. Retrieved from Transportation and communication infrastructure in Latin America: Lessons from Asia. Available at https://piie.com/ publications/wp/wp12-6.pdf.

Ministerio de Educación de Perú. (2017). Marco Curricular Nacional. Retrieved from Marco Curricular Nacional. Available at http:// www.minedu.gob.pe/curriculo/pdf/curriculo-nacional-2017. pdf.

OECD. (2016). Promoting productivity for inclusive growth in Latin America. Retrieved from Promoting productivity for inclusive growth in Latin America. Available at https://www.oecd.org/ latin-america/promoting-productivity-for-inclusive-growt h-in-latin-america.pdf.

Proética. (2015). Encuesta nacional sobre percepciones de la corrupcion 2015. Available at https://es.scribd.com/ document/292794637/Novena-Encuesta-nacional-sobrepercepciones-de-la-corrupcion-2015.

Project Management Institute, PMI. (1999). The role of trust in project management. In: Proceedings of the PMI Research Conference. Project Management Institute, Inc.

Provias Nacional. (2016). Intervenciones en la Red Vial Nacional. Available at http://www.proviasnac.gob.pe/Archivos/file/ RVN\%20presentacion/RVN_PERU_RTT_201601\%20(20160311). pdf.

Rafique Rahman, A. (1986). Legal and administrative measures against bureaucratic corruption in Asia in Bureaucratic Corruption in Asia: Causes, consequences and control. In: Cariño, L. V., \& Alfiler, M. C. (eds.), Bureaucratic Corruption in Asia-Causes, Consequences, and Controls. JMC Press, Manila, pp. 109-162.

The World Bank. (2014). World Development Indicators. Available at https://openknowledge.worldbank.org/bitstream/handle/109 86/18237/9781464801631.pdf. 
Van Rijckeghem, C., \& Weder, B. (1997). Corruption and the rate of temptation. Do low wages in the civil service cause corruption?. In: IMF working paper, 97/73.

Vanham, P. (2016). Éste es el año en que cambiará todo para América Latina. Available at: https://www.weforum.org/es/ agenda/2016/06/este-es-el-ano-en-que-cambiara-todo-paraamerica-latina/.

Watson, A. (2016). What makes a project manager competent? Available at https://www.apm.org.uk/blog/what-makes-competent-project-manager.
World Economic Forum, WEF. (2016). The Global Competitiveness Report 2015-2016. Available at http://www3.weforum. org/docs/gcr/2015-2016/Global_Competitiveness_ Report_2015-2016.pdf.

Zaghloul, R., \& Hartman, F. (2002). Construction contracts: The cost of mistrust. In: Proceedings of the IRNOP V Conference. Renesse, The Netherlands 